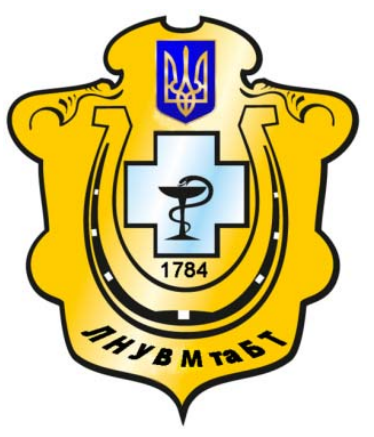

Науковий вісник Львівського національного університету ветеринарної медицини та біотехнологій імені С.3. Гжицького

Scientific Messenger of Lviv National University of Veterinary Medicine and Biotechnologies named after S.Z. Gzhytskyj

doi:10.15421/nvlvet7021

ISSN 2413-5550 print

ISSN 2518-1327 online

$\underline{\text { http://nvlvet.com.ua/ }}$

УДК 619:636.7:636.043:612.11:612.12:612.65

\title{
Морфологічні і біохімічні показники крові службових собак в постнатальному періоді онтогенезу
}

\author{
А.А. Дубовий, С.I. Шеремет \\ net_tolik73@mail.ru \\ Житомирський наџіональний агроекологічний університет, \\ Старий бульвар, 7, м. Житомир, 10002, Украӥна
}

\begin{abstract}
У статті представлено морфологічні та деякі біохімічні показники крові службових собак в постнатальному періоді онтогенезу (1, 7, 14 добового, 1, 2, 8, 12 місячного та 3 річного віку), вирощених в умовах розплідників м. Житомир. Встановлено, щуо вміст гемоглобіну і кількість еритроцитів у крові собак, починаючи з 1-ї доби після народження, зростає до 8-місячного віку і практично знаходиться на одному рівні у молодняку та дорослих собак 3 - 4-річного віку. Найменший вміст гемоглобіну діагностовано у иуценят 1, 7, 14-добового і 2 місячного віку, а найбільший його вміст - у собак 3 - 4 річного віку. Кількість еритрочитів у крові собак, вирощених в умовах розплідників змінювалася в залежності від віку. Найменша кількість еритроцитів діагностована у иуценят 1-,7- та 14-добового віку, а найбільша кількість - у статевозрілих собак 8 та 12 місячного віку. При цьому кількість еритроцитів у крові цих тварин була вірогідно (p < 0,01) більшою, ніж у иуценят попередніх вікових груп. Середнє значення кількості лейкоцитів у собак в постнатальному періоді онтогенезу було в межсах норми і практично не відрізнялось у всіх вікових групах.

Вміст загального білка у крові собак з віком змінювався. Найменший вміст діагностовано у собак 14 добового віку, а найбільший - у собак 3 - 4 річного віку. При цьому різниця була вірогідною $(p<0,01)$. Уміст альбумінів у крові собак різних вікових груп був у нормі і суттєво не відрізнявся. Вміст білірубіну, сечовини і креатиніну у крові собак в постнатальному періоді онтогенезу теж був в межах норми і суттєво не відрізнявся у собак різних вікових груп.

Ключові слова: собаки, иуценята, молодняк, еритроцити, гемоглобін, лейкоцити, загальний білок, альбуміни, білірубін, сечовина, креатинін.
\end{abstract}

\section{Морфологические и биохимические показатели крови служебных собак в постнатальном периоде онтогенеза}

\author{
А.А. Дубовый, С.И. Шеремет \\ net_tolik73@mail.ru
}

Житомирский национальный агроэкологический университет, Старый бульвар, 7, г. Житомир, 10002, Украина

В статье представлено морфологические и некоторые биохимические показатели крови служебных собак в постнатальном периоде онтогенеза (1, 7, 14 суточного, 1, 2, 8, 12 месячного и 3 летнего возраста), вырощенных в условиях питомников г. Житомир. Установлено, что содержание гемоглобина и количества эритроцитов в крови собак, начиная $c$ 1-х суток после рождения, увеличивается до 8-месячного возвраста и практически находится на одном уровне в молодняка и взрослых собак 3 - 4-летнего возраста. Наименьшее содержание гемоглобина диагностировано у щенков 1, 7, 14суточного и 2 месячного возраста, а наибольшее его содержание - у собак 3 - 4 летнего возраста. Количество эритроцитов в крови собак, вырощенных в условиях питомников изменялось в зависимости от возраста. Наименшее количество эритроцитов диагностировано у щеенков 1-,7-и 14-суточного возраста, а наибольшее - у половозрельх собак 8 и 12 месячного возвраста. При этом количество эритрочитов в крови этих животных было достоверно $(p<0,01)$

Citation:

Duboviy, A.A., Sheremet, S.I. (2016)._The morphological and biochemical parameters of blood of sniffer dogs in postnatal ontogenesis. Scientific Messenger LNUVMBT named after S.Z. Gzhytskyj, 18, 3(70), 91-94. 
больиим, нежили у щенков предыдуших возростных групп. Середнее значение количества лейкоиитов у собак в постнатальном периоде онтогенеза было в пределах нормы и практически не отличалось у всех возрастных групах.

Содержание общего белка в крови собак с возрастом менялось. Наименьшее содержание диагностировано у собак 14 суточного возраста, а наибольшее - у собак 3 - 4 летнего возраста. При этом разница была достоверной (р < 0,01). Содержание альбуминов в крови собак разных возрастных групп было в норме и существенно не отличалось. Содержание билирубина, мочевины и креатинина в крови собак в постнатальном периоде онтогенеза также было в пределах нормы и существенно не отличалось у собак разных возрастных групп.

Ключевые слова: собаки, щуенки, молодняк, эритроциты, гемоглобін, лейкоциты, общий белок, альбумины, билирубин, мочевина, креатинин.

\title{
The morphological and biochemical parameters of blood of sniffer dogs in post- natal ontogenesis
}

\author{
A.A. Duboviy, S.I. Sheremet \\ net_tolik73@mail.ru
}

\author{
Zhytomyr national agroecological university, \\ Staryj Boulevard, 7, Zhytomyr, 10002, Ukraine
}

The article presents the morphological and some biochemical parameters of blood of dogs in postnatal ontogeny (1, 7, 14 day, 1, 2, 8, 12 months and 3 years old), grown yield under nursery in conditions of Zhytomyr. The content of hemoglobin and number of erythrocytes in the blood of dogs, starting 1 day after birth, increases to 8-month age and almost on the same level in young and adult dogs 3-4 years of age. The least content of hemoglobin was diagnosed in puppies, 1, 7, 14 days and 2 months of age, and the greatest - in dogs 3 - 4 years of age. The number of erythrocytes in the blood of dogs, grown yield under nursery conditions were changed depending on age. The least number of erythrocytes was diagnosed in puppies, 1-,7-and 14-days age, and the highest in mature dogs, 8 and 12 month age. The number of erythrocytes in the blood of these animals was significantly $(p<0.01)$ more, than bathed in puppies of previous age groups. Average value of the number of leukocytes in dogs in postnatal ontogeny was in the normal range and did not differ from all age group.

The content of total protein in blood of dogs varied with age. The least content of it diagnosed in dogs 14 days of age, and the highest in dogs $3-4$ years of age. The difference was significant $(p<0.01)$. Albumin content in the blood of dogs of different age groups was normal and did not differ significantly. The content of bilirubin, urea and creatinine in the blood of dogs in a postnatal period of ontogenesis was also within normal limits and were not significantly different in dogs of different age groups.

Key words: dog, puppies, youngster, erythrocytes, hemoglobin, leukocytes, total protein, albumin, bilirubin, urea, creatinine.

\section{Ветуп}

Собаки - найдавніші і найвідданіші з тварин, яких приручила людина. I в умовах сьогодення вони займають важливе місце, мають народногосподарську і соціальну цінність (Dzhejms and Gaffon, 2001).

3 давніх часів службові собаки вірно служать людині. Вони охороняють ії дім, випасають худобу, спасають людей, використовуються у військових цілях, служать провідником сліпих і т.д. (Masilenis, 1992).

Дуже потрібні службові собаки і в наш час. Вони допомагають прикордонникам, охороняють важливі військові об'єкти, народне майно, затримують злочинців, надають допомогу розвідникам корисних копалень, знаходять місця витоку газу на трасах, шукають вибухові речовини, зброю, наркотичні засоби, нелегально перетнулих кордон людей.

На сьогодні особливо гостро потребує удосконалення та відповідної організації система діагностичних і лікувально-профілактичних заходів у кінологічних розплідниках, теоретичною і методичною основою яких є диспансеризація (Kondrahin et al., 1989; Fasolia, 2008).

Тому метою наших досліджень було визначити морфологічні і деякі біохімічні дослідження крові службових собак в постнатальному періоді онтогенезу в умовах розплідників м. Житомир.

Для вирішення мети потрібно було вирішити наступні завдання: сформувати 8 вікових груп клінічно здорових тварин по 10 голів в кожній;

провести морфологічні дослідження крові у тварин всіх вікових груп;

провести біохімічні дослідження сироватки крові у тварин всіх вікових груп;

провести аналіз результатів досліджень і зробити висновки.

\section{Матеріал і методи досліджень}

Роботу виконували на кафедрі внутрішніх хвороб тварин та фізіології факультету ветеринарної медицини Житомирського національного агроекологічного університету.

Об'єктом дослідження були службові клінічно здорові собаки 1-, 7-, 14- добового, 1-, 2-, 8місячного і 1-, 3-річного віку, які народились та утримувались в розплідниках МВС і колонії № 4 м. Житомир.

Відбір крові у цуценят-сисунів 1-, 7-, 14- добового віку виконували 3 яремної вени після 2-годинної перерви з моменту відлучення від лактуючої суки, у собак 1-, 2-, 8- місячного та 1-, 3- річного віку 3 підшкірної вени передпліччя $з$ дотриманням всіх правил асептики і антисептики. Для загального аналізу (вміст гемоглобіну, кількість еритроцитів) кров стабілізували цитратом натрію або гепарином. Уміст загального білку в сироватці крові досліджували рефрак- 
тометричним методом. Уміст альбумінів, загального білірубіну, сечовини і креатиніну в сироватці крові досліджували використовуючи напівавтоматичний біохімічний аналізатор. Дослідження проводили за загальноприйнятими методиками.

Результати досліджень обробляли методами варіаційної статистики за допомогою електронних таблиць MS Excel XP.

\section{Результати та їх обговорення}

Дослідження гематологічних показників свідчить про те, що вміст гемоглобіну у крові собак з віком зростає. Найнижчий вміст гемоглобіну діагностований у крові 1-, 7-, 14-добових цуценят і в середньому він становив відповідно $107,2 \pm 1,2$, $105,8 \pm 1,4$ та 91,25 $\pm 1,4$ г/л, при цьому ліміт становив від 89,2 до 110 г/л. (табл. 1) У крові 1-, 2-місячних цуценят вміст гемоглобіну знаходився у межах від 98,0 до 152,0 г/л і в середньому становив, відповідно, $137,3 \pm 3,8$ та $104,2 \pm 2,1$ г/л.
Найвищий вміст гемоглобіну був діагностований у дорослих 3 - 4-річних собак - 145 - 160,8 г/л (156,6 \pm 3,8 г/л).

Кількість еритроцитів у крові собак, вирощених в умовно чистій зоні щодо забруднення радіонуклідами, змінювалася в залежності від віку. Найменша кількість еритроцитів діагностована у цуценят 1-,7та 14-добового віку. Кількість еритроцитів у крові цуценят знаходилася в межах від 5,9 до 6,5 Т/л і в середньому становила, відповідно, $6,28 \pm 0,09,6,08 \pm$ 0,2 та 5,9 $\pm 0,03$ Т/л. У крові $1-, 2-$ місячних цуценят кількість еритроцитів знаходилася в межах від 4,6 до 7,0 Т/л і у середньому становила відповідно 6,9 $\pm 0,07$ та 6,2 $\pm 0,3$ Т/л. Аналіз стану еритроцитопоезу молодняку собак віком від 8 до 12-місяців свідчить про те, що кількість еритроцитів у крові цих тварин була вірогідно $(\mathrm{p}<0,01)$ більшою, ніж у цуценят попередніх вікових груп, при цьому ліміт знаходився на рівні від 4,6 до 8,0 Т/л і в середньому становив $7,7 \pm 0,2$ та 7,8 $\pm 0,23$ Т/л (табл. 1$)$.

Морфологічні показники крові у собак в постнатальному періоді онтогенезу, $\mathrm{M} \pm \mathrm{m}$

\begin{tabular}{|l|c|c|c|}
\hline \multirow{2}{*}{ Вік тварин } & \multicolumn{3}{|c|}{ Показники } \\
\cline { 2 - 4 } & еритроцити, Т/л & гемоглобін, г/л & лейкоцити, Г/л \\
\hline 1 доба & $6,28 \pm 0,09$ & $107,2 \pm 1,2$ & $9,45 \pm 0,3$ \\
\hline 7 діб & $6,08 \pm 0,2$ & $105,8 \pm 1,4$ & $9,19 \pm 0,2$ \\
\hline 14 діб & $6,1 \pm 0,07$ & $91,25 \pm 1,4$ & $9,5 \pm 0,2$ \\
\hline 1 місяць & $6,9 \pm 0,07$ & $137,3 \pm 3,9$ & $9,2 \pm 0,4$ \\
\hline 2 місяці & $6,2 \pm 0,3$ & $104,2 \pm 2,1$ & $9,5 \pm 0,3$ \\
\hline 8 місяців & $7,7 \pm 0,2$ & $129,6 \pm 6,1$ & $9,2 \pm 0,15$ \\
\hline 1 рік & $7,8 \pm 0,2$ & $152,8 \pm 2,4$ & $8,98 \pm 0,15$ \\
\hline $3-4$ роки & $7,5 \pm 0,1$ & $156,6 \pm 3,8$ & $10,3 \pm 0,7$ \\
\hline
\end{tabular}

Отже, аналізуючи стан еритроцитопоезу собак різного віку контрольних груп варто зазначити, що вміст гемоглобіну і кількість еритроцитів у крові собак, починаючи 3 1-ї доби після народження, зростає до 8-місячного віку і практично знаходиться на одному рівні у молодняку та дорослих собак 3-4річного віку.

Середнє значення кількості лейкоцитів у всіх вісьмох вікових групах було в межах норми і суттєво не відрізнялось (табл. 1). Профіль лейкограми у собак в постнатальному періоді онтогенезу був нейтрофільний. Базофіли майже відсутні. Кількість еозинофілів, нейтрофілів паличкоядерних, сегментоядерних, лімфоцитів знаходилась у межах норми в усіх вікових групах собак і суттєво не відрізнялася у молодняку і дорослих тварин.

Одним із показників функціонального стану печінки у тварин є вміст загального білка. Вміст загального білка у сироватці крові дещо відрізняється у собак різних вікових груп. У цуценят 1-, 7-, 14 добового віку вміст загального білка у сироватці крові знаходився на рівні 46,1 - 60,8 г/л і в середньому становив, відповідно, 51,4 $\pm 1,8,58,3 \pm 0,9$ та 49,3 \pm 0,8 г/л. У крові 1- i 2-місячних цуценят вміст загального білка збільшувався порівняно з 1,7 і 14 добовими і знаходився в межах від 57,7 до 63,6 г/л, при цьому різниця була вірогідною $(\mathrm{p}<0,01)$ (табл. 2).

У крові молодняку собак 8-місячного та 1-річного віку вміст загального білка знаходився в межах від 60 до 71,3 г/л і в середньому становив $62,3 \pm 1,8$ та $66,4 \pm$ 1,4 г/л, відповідно. У дорослих собак 3-4-річного віку вміст загального білка вірогідно не відрізнявся від молодняку 8-місячного та 1-річного віку - 68,2 \pm 1,6 г/л $(61,0-81,8$ г/л).

Отже, аналіз визначення вмісту загального білка у сироватці крові собак свідчить про поступове зростання його вмісту у залежності від віку тварин, адже найнижчий його вміст виявлений у 14-добових цуценят (49,3 \pm 0,8 г/л), найбільший - у 3-4-річних собак $(68,2 \pm 1,6$ г/л).

За результатами наших досліджень вміст альбумінів у цуценят 1,7 i 14 -добового віку знаходиться в межах від 24,0 до 34,0 г/л, у 1 і 2місячних - від 28,6 до 32,5 г/л, у 8 і 12-місячних - від 31 до 34,2 г/л (табл. 2), що свідчить про відсутність суттєвої різниці у вмісті альбумінів у сироватці крові собак.

Така закономірність у сталому рівні альбумінів у сироватці крові клінічно здорових собак пояснюється задовільною білоксинтезувальною функцією печінки. 


\begin{tabular}{|c|c|c|c|c|}
\hline \multirow[b]{2}{*}{ Вік тварин } & \multirow[b]{2}{*}{ Загальний білок, г/л } & \multirow{2}{*}{\multicolumn{2}{|c|}{ Альбуміни }} & \multirow{2}{*}{$\begin{array}{c}\text { Загальний } \\
\text { білірубін, ммоль/л }\end{array}$} \\
\hline & & $\Gamma / \pi$ & & \\
\hline 1 доба & $51,4 \pm 1,85$ & $26,5 \pm 1,56$ & $51,47 \pm 1,5$ & $5,7 \pm 0,3$ \\
\hline 7 діб & $58,3 \pm 0,99$ & $31,1 \pm 0,89$ & $53,3 \pm 1,4$ & $5,3 \pm 0,6$ \\
\hline 14 діб & $49,3 \pm 5,62$ & $26,9 \pm 0,73$ & $54,5 \pm 0,9$ & $1,8 \pm 0,4$ \\
\hline 1 місяць & $63,2 \pm 1,12$ & $32,1 \pm 0,94$ & $50,8 \pm 0,8$ & $3,25 \pm 0,7$ \\
\hline 2 місяці & $59,1 \pm 0,8$ & $29,7 \pm 0,45$ & $50,2 \pm 0,6$ & $1,9 \pm 0,2$ \\
\hline 8 місяців & $62,3 \pm 1,8$ & $31,9 \pm 1,85$ & $51,2 \pm 2,1$ & $3,9 \pm 0,2$ \\
\hline 1 рік & $66,4 \pm 1,4$ & $34,1 \pm 0,86$ & $51,4 \pm 0,7$ & $4,57 \pm 0,2$ \\
\hline 3-4 роки & $68,2 \pm 1,6$ & $29,7 \pm 0,79$ & $43,5 \pm 0,6$ & $3,52 \pm 0,1$ \\
\hline
\end{tabular}

Важливим показником пігментного обміну печінки є вміст білірубіну в сироватці крові собак. За результатами наших досліджень, вміст загального білірубіну у цуценят 1,7 i 14-добового віку знаходиться в межах від 0,78 до 6,7 мкмоль/л, у 1 і 2 місячних - від 1,4 до 5,91 мкмоль/л, у молодняку 8місячного та 1-річного віку від 3,21 до 5,0, у дорослих 3-4-річних - від 4,21 до 4,5 мкмоль/л, при цьому найнижчий його вміст діагностували у собак 14добового та 2-місячного віку (відповідно $1,8 \pm 0,4$ та $1,9 \pm 0,2$ мкмоль/л), а найвищий - у цуценят 1добового віку (табл. 2).

Одним із показників функціонального стану печінки, що характеризує білковий обмін, $є$ вміст сечовини в сироватці крові тварин.

Ліміти вмісту сечовини у цуценят 1,7 та 14добового віку знаходяться в межах від 4,04 до 6,7 ммоль/л, у молодняку собак 8-, 12-місячного віку від 4,7 до 7,2 ммоль/л, у дорослих 3-4-річних собаквід 2,9 до 7,7 ммоль/л (табл. 3).

Отже, враховуючи одержані нами результати, необхідно зазначити, що в усіх собак знешкодження аміаку печінкою проходить на достатньому рівні.

Фільтраційну функцію клубочків нирок у собак контрольних груп оцінювали за вмістом креатиніну у сироватці крові тварин. Ліміти вмісту креатиніну в сироватці крові собак від 1-добового до 3-4-річного віку були в межах від 61,5 до 128,5 мкмоль/л.

Таблиия 3

Функціональний стан нирок у клінічно здорових собак в постнатальному періоді онтогенезу, (М \pm m)

\begin{tabular}{|c|c|c|c|c|}
\hline \multirow{2}{*}{ Вік тварин } & \multicolumn{2}{|c|}{ Креатинін, мкмоль/л } & \multicolumn{2}{c|}{ Сечовина, ммоль/л } \\
\cline { 2 - 5 } & ліміт & середній показник & ліміт & середній показник \\
\hline 1 доба & $58,3-78,3$ & $67,8 \pm 3,13$ & $5,2-6,4$ & $6,05 \pm 0,21$ \\
\hline 7 діб & $69,2-99,1$ & $84,2 \pm 4,23$ & $5,78-6,7$ & $6,2 \pm 0,15$ \\
\hline 14 діб & $58,2-128,5$ & $93,8 \pm 9,99$ & $4,0-6,7$ & $5,3 \pm 0,40$ \\
\hline місяць & $73,9-109,5$ & $93,7 \pm 5,67$ & $4,4-6,9$ & $6,51 \pm 0,38$ \\
\hline 2 місяці & $58,8-88,5$ & $73,3 \pm 4,55$ & $3,5-5,6$ & $4,4 \pm 0,32$ \\
\hline 8 місяців & $77,2-100,6$ & $84,23 \pm 3,47$ & $5,3-7,2$ & $6,7 \pm 0,27$ \\
\hline 1 рік & $89,4-123,5$ & $106,45 \pm 5,90$ & $4,7-7,2$ & $6,3 \pm 0,31$ \\
\hline 3-4 роки & $53,0-119,15$ & $90,4 \pm 4,25$ & $2,8-7,7$ & $5,51 \pm 0,39$ \\
\hline
\end{tabular}

Вірогідної різниці рівня креатиніну у собак різних вікових груп не встановлено: у 1, 7 і 14-добових він знаходиться в межах від 58,2 до 128,5 мкмоль/л, 1-2місячних - від 58,8 до 109,5, мкмоль/л, 8 і $12-$ місячних - від 75,9 до 123,5 та 3-4-річних - від 53 до 115,3 мкмоль/л (табл. 3).

\section{Висновки}

1. Вміст гемоглобіну i кількість еритроцитів у крові собак, починаючи з 1-ї доби після народження, зростає до 8-місячного віку і практично знаходиться на одному рівні у молодняку та дорослих собак 3-4річного віку.

2. Найменший вміст гемоглобіну діагностовано у цуценят 1, 7, 14-добового i 2 місячного віку, а найбільший його вміст - у собак 3-4 річного віку.

3. Кількість еритроцитів у крові статевозрілих собак 8 та 12 місячного віку була вірогідно $(\mathrm{p}<0,01)$ більша, ніж у цуценят 1-,7-та 14-добового віку.

4. Вміст загального білка у крові собак 3 віком змінювався: найменший вміст діагностовано у собак 14 добового віку, а найбільший - у собак 3-4 річного віку. При цьому різниця була вірогідною $(\mathrm{p}<0,01)$.

5. Найменший рівень загального білірубіну діагностували в крові собак 14-добового і 2-місячного віку, а найбільший - у цуценят добового віку.

6. Вміст креатиніну і сечовини в сироватці крові собак у всіх вікових групах суттєво не відрізнявся і не виходив за фізіологічні межі.

\section{Бібліографічні посилання}

Karlson, D. Delbert, Dzhejms M. (2001). Domashnij veterinarnyj spravochnik dlja vladel'cev sobak. M. Centrpoligraf (in Russian).

Masilenis, K. (1992). Sluzhebnoe i dekorativnoe sobakovodstvo, Vil'njus: Gorizont (in Russian).

Kondrahin, I.P., Kesarev, E.A., Zybrilova, L.S. (1989). Rekomendacii po dispanserizacii slyjebnih sobak. M. Gosagroprom SSSR (in Russian).

Fasolia, V.P. (2008). Dyspanseryzatsiia sobak sluzhbovykh porid: dys... d-ra. vet. nauk: spets. 16.00.01 «Diahnostyka i terapiia tvaryn, Bila Tserkva. 6-14 (in Ukrainian).

Стаття надійшла до редакиії 2.10.2016 